\title{
Penerapan Komunikasi Terapeutik Pada Proses Penyembuhan Pasien Di Bangsal Keperawatan RSUD Kota Semarang
}

\author{
Dinita Yularsih \\ (heidan_dinita55@yahoo.co.id) \\ (Alumni Jurusan Ilmu Komunikasi Universitas Semarang)
}

\begin{abstract}
Dinita Yularsih. G.331.100.019. Application of Therapeutic Ccommunication in The Healing Process of Patients in Nursing Wards in General Hospitals Semarang Skripsi : Program S-1 Study of Communication Studies University of Semarang. This study aims to determine the effectiveness of the application of therapeutic communication in nursing wards General Hospital Semarang, and how much influence can give satisfaction to the customer as a hospital patient. The foundation of the theory used in this study is the theory of interpersonal communication, persuasive communication, symbolic interaction, and therapeutic communication. The research method used is the deskriptive qualitative.Teknique qualitative method of data collection is done by in-depth interviews and observation, data collection techniques by purposive sampling technique. This study involves a Physician Specialist, Head of Nursing, in patient room nurses, and hospital patients Semarang in accordance with the criteria previously specified writer. Concluded that therapeutic communication is applied by doctors and nurses in hospitals Semarang going very well on the healing process of the patient. Application not only in the nursing ward, but has started since the patient was still in the clinic. With the implementation of therapeutic communication is expected the patient will feel comfortable while undergoing treatment in hospital and were satisfied with the services provided by the hospital in Semarang.
\end{abstract}

Kata Kunci : Komunikasi Terapeutik, Keperawatan, RSUD Kota Semarang

\section{PENDAHULUAN}

Sebagai mahluk sosial manusia senantiasa inginberhubungan dengan manusia lainnya. Ingin mengetahui lingkungan sekitarnya, bahkan ingin mengetahui apa yang terjadi dalam dirinya. Rasa ingin tahu ini memaksa manusia perlu berkomunikasi. Komunikasi adalah suatu kebutuhan yang fundamental bagi seseorang dalam hidup bermasyarakat. Secara etimologis atau menurut asal katanya komunikasi atau communication dalam bahasa Inggris.
Dalam bahasa Latin communis yang berarti "sama", communico, communicatio, atau communicare yang berarti 'membuat sama'(to make common). Istilah pertama (communis) adalah istilah yang paling sering disebut sebagai asal-usul kata komunikasi, yang merupakan akar dari kata-kata Latin lainnya yang mirip.

Komunikasi menyarankan bahwa suatu pikiran, suatu makna,dianut secara sama (Mulyana 2002 : 
41).Hakekat komunikasi adalah proses pernyataan antar mannusia, yang dinyatakan adalah pikiran atau perasaan seseorang kepada orang lain dengan menggunakan bahasa sebagai alat penyalurannya. Menurut Carl I Hovland dalam Fajar (2009 : 37), komunikasi adalah suatu proses dimana seseorang memindahkan perasaan yang biasanya lambang atau kata-kata untuk mengubah tingkah laku orang lain. Selanjutnya Fajar (2009:39) mengemukakan bahwa: "Komunikasi memang berlangsung dari kesengajaan di mana fungsi dari komunikasi itu sendiri adalah menginformasikan (to inform), mendidik (to educate), menghibur (to entertain), mempengaruhi (to influence)".

Karena begitu pentingnya

komunikasi, maka komunikasi dapat juga dijadikan alat terapi / suatu metode tetapi pada profesi-profesi tertentu, yang dalam menjalankan tugasnya sangat sering berhubungan dengan orang lain. Biasanya kegiatan tersebut adalah berhubungan dengan profesi psikologi, konseling kesehatan medis atau keperawatan, dan klinik alternatif, sehingga komunikasi dapat berfungsi sebagai alat terapi yang kemudian disebut "komunikasi terapeutik". Dengan menguasai komunikasi terapeutik, diharapkan seseorang akan lebih efektif bekerja dan lebih mudah menjalin hubungan saling percaya dengan klien (Mangunjaya, 2001 : 20).

Rumah sakit sebagai salah satu organisasi sektor publik yang bergerak dalam bidang pelayanan jasa kesehatan yang mempunyai tugas melaksanakan suatu upaya kesehatan secara berdaya guna dan berhasil guna dengan mengutamakan atau mementingkan upaya penyembuhan dan pemulihan yang telah dilaksanakan secara serasi dan terpadu oleh pihak rumah sakit dalam upaya peningkatan dan pencegahan penyakit serta upaya perbaikan.
(Keputusan Menteri Kesehatan Republik Indonesia No. 983/Men/SK/XI/1992) Rumah sakit tidak hanya sekedar menampung orang sakit saja melainkan harus lebih memperhatikan aspek kepuasan bagi para pemakai jasanya, dalam hal ini pasien.

Kemajuan ilmu pengetahuan dan teknologi kedokteran serta perubahan konsep perawatan orang sakit secara individual ke perawatan paripurna yaitu pelayanan kesehatan meliputi peningkatan kesehatan (promotif), pencegahan penyakit (preventif), penyebuhan peyakit (kuratif), dan pemulihan (rehabilitatif) yang dilaksanakanan secara serasi dan berkesinambungan.(Siregar, 2004) menyebabkan peranan komunikasi menjadi lebih penting dalam pemberian asuhan keperawatan. Keperawatan pada intinya adalah sebuah proses interpersonal, maka perawat yang kompeten harus menjadi seorang komunikator yang efektif dan setiap perawat mempunyai tanggungjawab untuk memperhatikan perkembangannya sendiri di bidang ini. (Peplau, 1998 dalam Ellis, 2000 : 9)

Komunikasi yang tidak efektif juga bisa mengakibatkan tidak puasnya klien dan keluarganya terhadap pelayanan keperawatan termasuk komunikasi. (Suryani, 2005 : 80). Seperti yang disampaikan Sani Sanusi pada majalah perumahsakitan No 34 tahun 1995 dalam buletin PPNI bahwa pada umumnya hampir sebagian besar perawat dan rumah sakit di Indonesia masih kurang berkomunikasi dengan pasiennya. Di surat kabar sering kita baca banyaknya keluhan dari masyarakat terhadap pelayanan di rumah sakit. Setelah ditelusuri salah satu penyebab yang paling banyak mengakibatkan kekecewaan masyarakat adalah akibat kesalahan komunikasi antara perawat dengan pasiennya dan keluarganya. 
Suatu studi yang pernah dilakukan oleh Technical Assistance Research Programmer untuk The White House Office Of Consumer Affairs mengatakatan jika pelanggan tidak puas akan berakibat : $90 \%$ dari pelanggan yang tidak puas itu, tidak akan datang kembali, setiap orang yang tidak terpuaskan keinginannya, akan meceritakan paling sedikit kepada 9 orang teman atau kerabatnya, 13\% dari pelanggan yang kecewa akan menceritakan kejadian tersebut kepada lebih dari 20 orang.

Jika diamati secara lebih cermat, kepuasan pelanggan banyak ditentukan oleh kualitas performa pelayanan di lapangan. Bila pelayanan tidak sama atau tidak sesuai dengan harapan pelanggan, maka di mata pelanggan pelayanan yang diberikan dinilai jelek (Yoeti, 1999 : 31). Sekalipun perawat sudah memahami tentang cara berkomunikasi yang efektif dengan klien, pada kenyataannya terkadang perawat tidak mampu melakukannya dengan baik. Hal ini mungkin disebabkan adanya hambatan, baik yang datang dari klien maupun dari perawat (Suryani, $2005: 86$ )

\section{Perumusan Masalah}

Dari Latar Belakang yang telah diuraikan diatas, maka perumusan masalah yang dapat ditarik dalam penelitian ini adalah

a. Bagaimana penerapan komunikasi terapeutik pada proses penyembuhan pasien di bangsal keperawatan RSUD kota Semarang ?

b. Bagaimana komunikasi terapeutik yang diterapkan di bangsal keperawatan dapat memberikan kepuasan pada pelanggan di RSUD kota Semarang?

\section{Tujuan Penelitian}

a. Untuk mengetahui sejauh mana pelaksanaan komunikasi terapeutik yang diterapkan pada proses penyembuhan pasien di bangsal keperawatan di RSUD kota Semarang.

b. Untuk mengetahui pelaksanaan komunikasi terapeutik yang dipraktekkan di bangsal keperawatan dapat memberikan kepuasan pada pelanggan di RSUD kota Semarang.

\section{Tinjauan Pustaka}

\section{Komunikasi Interpersonal}

Komunikasi interpersonal adalah komunikasi antara orang-orang secara tatap muka, yang memungkinkan setiap pesertanya menangkap reaksi orang lain secara langsung, baik verbal maupun non verbal. Komunikasi interpersonal ini biasanya dilakukan oleh dua orang, seperti suami istri, dua sejawat, dua orang sahabat dekat, guru-murid, dan sebagainya ( Mulyana, 2000, p.73).

\section{Komunikasi Persuasif}

Menurut Pfau dan Perot (2001 :

2) persuasif adalah "persuasion as the shaping, changing or reinforcing $o$ receivers responses, including attitudes, emotions, and behaviors". Teori tersebut menunjukkan adanya kesamaan pendapat bahwa dalam komunikasi persuasif terdapat unsurunsur sebagai berikut : adanya bentuk/model, penguatan dan perubahan tanggapan serta termasuk didalamnya adalah sikap, emosi dan kehendak perilaku. Komunikasi persuasif adalah"suatu pesan yang disampaikan dengan menggunakan 
pendekatan pribadi, bersifat ajakan dan tidak memaksa kepada orang lain sehingga komunikan (penerima pesan) dengan penuh kesadaran memahami dan merubah sikap sesuai dengan yang diinginkan komunikator"

\section{Interaksionisme Simbolik}

Interaksi simbolik adalah interaksi yang mengarahkan perhatian seseorang pada interaksi antar individu, dan bagaimana hal tersebut bisa dipergunakan untuk mengerti apa yang orang lain katakan dan lakukan kepada individu lain yang melibatkan suatu pertukaran simbol ketika seseorang berinteraksi dengan orang lain. Interaksionisme simbolik dalam komunikasi terapeutik perawat bukanlah hal asing dengan adanya interaksi kelompok terhadap individu. Keterkaitan tersebut nampak dalam bentuk peran serta kelompok profesional yang dalam proses kesembuhan pasien yang sangat dibutuhkan, baik dari sentuhan, perhatian dan penyampaian pesan secara halus yang membuat kenyamanan tersendiri bagi pasien. Seperti yang terjadi dalam praktek keperawatan berdasarkan interaksionisme simbolik bahwa para perawat di lingkungan RSUD kota Semarang mengungkapkan bahwa interaksi pada saat proses penyembuhan pada pasien sangat berperan besar bagi kesembuhan pasien.

\section{Komunikasi Terapeutik}

Komunikasi terapeutik adalah komunikasi yang direncanakan secara sadar, dan bertujuan dan kegiatannya dipusatkan untuk kesembuhan pasien. Komunikasi terapeutik termasuk komunikasi interpersonal dengan titik tolak saling memberikan pengertian antar perawat dengan pasien. Persoalan mendasar dan komunikasi ini adalah adanya saling membutuhan antara perawat dan pasien, sehingga dapat dikategorikan ke dalam komunikasi pribadi di antara perawat dan pasien, perawat membantu dan pasien menerima bantuan (Indrawati, 2003 : 48).

\section{Hasil dan Pembahasan}

Hasil penelitian ini menggunakan pendekatan kualitataif deskriptif, maka ditemukanlah beberapa temuan penelitian yang berkaitan dengan penerapan komunikasi terapeutik di RSUD kota Semarang sebagai berikut :

\section{Deskripsi mengenai penerapan komunikasi terapeutik pada proses penyembuhan pasien di bangsal keperawatan di RSUD kota Semarang.}

Dari pendapat beberapa Narasumber mengenai pelaksanaan atau penerapan komunikasi terapeutik di rumah sakit terutama ketika dikaitkan dengan seberapa besar dapat mempengaruhi proses penyembuhan pasien di bangsalkeperawatan, menurutpendapat Narasumber dari tim medis yaitu dokter Spesialis Anak dan Spesialis penyakit Dalam, komunikasi secara personal / terapeutik, sangat penting diterapkan pada proses penyembuhan pasien, karena tanpa komunikasi, dokter tidak mungkin mengetahui perkembangan yang terjadi dengan pasiennya, baik perkembangan 
ke arah positif atau negatif. Penerapan komunikasi terapeutik tidak hanya berlangsung di bangsal keperawatan saja, namun komunikasi terapeutik secara tidak langsung sudah terjadi ketika seseorang datang ke rumah sakit sebagai pasien.

Penerapan komunikasi terapeutik dapat diawali dengan sapaan yang hangat dari seorang dokter, seperti contoh yang dijelaskan oleh kedua Narasumber tersebut bahwa percakapan pertama dengan pasien merakalah yang membukanya dengan berkata : "Selamat pagi/siang, Pak, ada yang dikeluhkan ?", atau bila pasiennya adalah anak-anak, dengan kata-kata seperti berikut :" Selamat pagi bu, anaknya sakit apa ? interaksi seperti ini pada umunya terjadi di poliklinik.

Di poliklinik, dokter akan; mencatat anamnesis pasien, memeriksa keadaan fisik pasien lengkap dari kepala sampai kaki. Dari catatan anamnesis dan pemeriksaan awal tersebut dokter akan menegakkan diagnosis pasien, dilanjutkan dengan pemeriksaan laboratorium, setelah itu baru diputuskan kondisi pasien apakah bisa langsung pulang dengan cukup meminum obat yang diresepkan oleh dokter atau jika hasil laboratoriumnya jelek, maka pasien harus menjalani rawat inap.

Di bangsal keperawatan, komunikasi antara dokter dan pasien berlangsung pada saat dokter mengunjungi pasien setiap hari selama satu kali, dan menjadi waktu yang tepat bagi pasien untuk menginformasikan perubahan atau perkembangan yang terjadi setelah menerima tindakan medis dari dokter. Apabila obat yang diminum atau yang dimasukkan melalui selang infus membawa perubahan ke arah yang lebih baik, dokter akan meneruskan kurang lebih selama dua-tiga hari kemudian dievaluasi. Jika hasil laboratoriumnya juga baik, dokter akan mengjinkan pasien untuk pulang.

Berinteraksi dalam bentuk sebuah penjelasan kepada pasien bila masih mungkin diajak berdialog bagi Narasumber dari tim medis yang merupakan perawat di bangsal keperawatan memang menjadi sebuah keharusan, hal ini dimaksudkan untuk membangun rasa saling percaya antara pasien beserta keluarganya, bahwa tindakan medis yang dilakukan, diambil dan dilaksanakan dengan sepengetahuan pihak keluarga. Menurut Narasumber yang juga perawat di bangsal ICU, interaksi yang bersifat komunikasi terapeutik yang diterapkan pada pasien atau keluarganya dimaksudkan agar memberikan rasa nyaman, terjalinnya hubungan yang bersahabat/dekat antara perawat, pasien maupun keluarganya. Serta timbulnya rasa percaya dari pihak keluarga bahwa anggota keluarganya yang saat ini sedang sakit di ICU mendapatkan perawatan yang terbaik dari rumah sakit.

Menurut pendapat Narasumberdari kalangan perawat senior yang memiliki banyak pengalaman selama menjadi perawat di beberapa bangsal keperawatan, banyak hal yang harus diperhatikan oleh seorang yang berprofesi sebagai perawat rumah sakit selain menjadi pelaksana dari instruksi dokter, membangun hubungan yang baik dengan pasien atau keluarganya menjadi sebuah keharusan agar stigma yang sudah terlanjur melekat di benak masyarakat luas tentang sikap para perawat di rumah sakit Negeri yang cenderung jutek dan galak serta kurang memperhatikan pasien atau keluarganya perlahan- lahan dapat terhapus dengan diterapkannya komunikasi terapeutik ini. 


\section{Deskripsi mengenai penerapan komunikasi terapeutik yang diterapkan di bangsal keperawatan dapat memberikan kepuasan pada pelannggan.}

Kepuasan pelanggan terhadap pelayanan yang diberikan pihak rumah sakit terkait dengan penerapan komunikasi terapeutik di bangsal keperawatan, berdasarkan hasil wawancara yang peneliti lakukan, dari keterangan dua orang Narasumber yang pernah menjadi pasien di RSUD, mengatakan bahwa mereka merasa cukup puas dengan komunikasi dua arah yang dilakukan oleh dokter dan pasiennya dilaksanakan dengan cukup baik, meski secara kuantitas sebenarnya komunikasi di bangsal keperawatan sangat singkat terjadi.

hal ini dikarenakan dari semenjak pasien masuk rumah sakit baik lewat poliklinik mau pun ruang IGD, dokter yang bertugas di kedua ruang tersebut telah membuat catatan anamesis pasien, dan telah membuat adminose (surat keterangan dari Dr poliklinik atau dari ruang IGD kalau pasien tersebut harus di rawat secara inap, biasanya dimasukkan jadi satu di dalam stopmap status pasien ). Namun demikian pada saat kunjungan dokter itulah pasien dapat menceritakan tentang pekembangan yang telah terjadi setelah dokter menerapkan metode pengobatan pada pasien, apakah menjadi lebih baik atau bila ada keluhan lain karena efek yang timbul setelah menkonsumsi obat misalnya jadi pusing atau mual, dokter akan menggganti dengan obat lain yang tidak menimbulkan rasa pusing atau mual.

Menurut pendapat Narasumber dari pasien yang pernah dirawat di ruang Arimbi karena sakit typus, sebagai pasien, menurut pendapatnya, dirinya memang tidak berbicara panjang lebar pada dokter yang menanganinya. Komunikasi yang berlangsung cukup singkat, dirinya hanya menjawab beberapa pertanyaan dari dokter seperti; apakah panasnya sudah turun, mual di perut sudah berkurang, dan kepalanya sudah tidak pusing lagi? Begitu dokter menanyainya. Disamping dirinya yang menjawab, istrinya juga ikut andil memberikan keterangan pada dokter mengenai penyebab dan kronologi bagaimana suaminya bisa sampai jatuh sakit. Setelah itu dokter mengatakan padanya bila dalam waktu satu atau dua hari lagi sudah tidak ada yang dikeluhkan disertai dengan hasil laboratorium yang baik, dokter akan mengijinkan dirinya pulang.

Jadi menurutnya yang menjadi unsur kepuasan pelanggan dari bentuk pelayanan kesehatan yang diperolehnya selama menginap di RSUD dikarenakan dokter dapat dengan cepat merespon keterangan dari pasien dan segera menarik kesimpulan baik dalam hal menegakkan diagnosa pasien atau ketepatan seorang dokter ketika memutuskan tindakan medis yang bagaimana yang harus diterapkan pada pasien setelah mengetahui jenis peyakitnya. Narasumber yang merupakan pasien yang pernah menjalani rawat inap mengatakan bahwa bukan berapa lama berlangsungnya komunikasi antara dirinya, dokter dan perawat, namun bagaimana hasil dari komunikasi yang terjadi di antara ketiganya dapat menjadi informasi yang berharga bagi proses penyembuhan pasien.

\section{Pembahasan}

Berdasarkan hasil wawancara mendalam dari beberapa orang Narasumber tentang Bagaimana 
Penerapan Komunikasi Terapeutik Pada Proses Penyembuhan Pasien di Bangsal Keperawatan, yaitu komunikasi secara interpersonal/terapeutik yang berlangsung antara Dokter, Pasien, dan Perawat, dalam penerapannya, komunikator atau pengirim pesan menyampaikan pesan atau informasi berupa kata-kata kepada imenggunakan suara manusia sebagai medianya (human voice) seperti yang diutarakan oleh Bittner, (1985 : 10)

Komunikasi terapeutik yang berlangsung antara komunikator dengan komunikan di RSUD ini dilakukan secara; fae to face atau bertatap muka, biasanya antara dokter dengan pasien atau keluarganya, perawat dengan pasien, atau dokter dengan perawat. Karena berlangsung secara tatap muka, maka reaksi atau tanggapan dari komunikator atau dari komunikan dapat diketahui saat itu juga, baik dalam bentuk lisan maupun disertai dengan bahasa tubuh atau non verbal. Seperti yang terjadi di bangsal keperawatan, ketika dokter bertanya pada pasiennya tentang perubahan apa yang telah terjadi setelah mengkonsumsi obat yang diberikan dokter, saat itu juga pasien akan memberikan keterangan dengan jelas pada dokter, kalau obat yang diminum atau cairan infus yang masuk ke pembuluh darah dapat diterima dengan baik oleh tubuh pasien. Begitu juga sebaliknya, jika timbul alergi, pasien akan mengatakannya pada dokter. Komunikasi antarpribadi adalah interaksi tatap muka antar dua atau beberapa orang, dimana pengirim dapat menyampaikan pesan secara langsung dan penerima pesan dapat menerima dan menanggapi secara langsung pula, seperti pendapat yang diutarakan oleh Agus M. Hardjana, (2003 : 85)
Komunikasi dua arah yang terjalin antara dokter-pasien ini akan menjadi masukan berharga bagi dokter untuk mengambil tindakan selanjutnya bagi pasien. Pelaksanaan secara baik mengenai komunikasi terapeutik ini dapat dilihat dari kunjungan dokter secara rutin di bangsal keperawatan atau ruang rawat inap pada pasiennya yang dilakukan setiap hari selama satu kali, dan hal ini dicatat oleh perawat yang selalu mendampingi dokter selama jam kunjungan dokter berlangsung. Dari catatan tersebut kemudian dokter selaku penanggung jawab pasien akan mendiskusikannya dengan perawat rawat inap, untuk selanjutnya dibahas apakah sistem pengobatan yang telah diterapkan pada pasien akan dilanjutkan sampai pasien memperoleh kesembuhan, atau dihentikan/diganti karena reaksinya negatif. Kegiatan mengunjungi pasien tersebut dilakukan oleh dokter rutin setiap hari selama pasien masih menjalani proses penyembuhan.

Menyangkut tentang kepuasan pasien selaku pelanggan rumah sakit berkaitan dengan penerapan komunikasi terapeutik pada proses penyembuhan pasien di bangsal keperawatan RSUD kota Semarang, berdasarkan hasil wawancara dengan Narasumber yang merupakan pasien atau pelanggan di RSUD kota Semarang menyatakan bahwa;

Pelayanan kesehatan yang diberikan oleh RSUD selama pasien menjalani proses penyembuhan di bangsal keperawatan cukup memuaskan, dikarenakan pasien merasa nyaman dengan suasana rumah sakit yang bersahabat dengan pasien, diantaranya; sapaan hangat dari dokter sewaktu bertemu dengan pasien, komunikasi yang bersahabat dengan perawat, serta dokter dan perawat yang cukup kooperatif dan mau mendengarkan 
segala masukan dari pasien.Pasien merasa dihargai dan dilayani dengan sepenuh hati tanpa membeda-bedakan pasien berdasarkan status administrasinya.

\section{Kesimpulan}

Berdasarkan penelitian yang telah dilakukan oleh peneliti mengenai komunikasi terapeutik di bangsal keperawatan, dapat disimpulkan bahwa penerapannya cukup baik pada proses penyembuhan pasien dan dapat mempengaruhi kadar kepuasan pasien selaku pelanggan. Hal ini dapat dilihat dari hasil komunikasi awal yang terjalin antara dokter dengan pasien, menjadi jawaban atas kondisi fisik pasien.

Kondisi fisik atau klinis yang sudah menjadi diagnosa, dapat menjadi acuan bagi dokter untuk menentukan tindakan medis atau sistem pengobatan yang akan diterapkan pada proses penyembuhan pasien. Proses penyembuhan dapat dijalani secara rawat jalan atau rawat inap tergantung dari diagnosa pasien. Pasien yang diputuskan menjalani rawat inap akan menjalani proses penyembuhan dengan cara menginap di rumah sakit di bangsal keperawatan.

Pada saat seseorang diputuskan menjadi pasien rawat inap, maka semua hal yang berkaitan dengan tindakan medis atau proses pengobatan untuk kesembuhan pasien, menjadi tugas perawat ruangan untuk menginformasikannya kepada pasien atau keluarganya.

Pasien selaku pelanggan RSUD akan merasa puas dengan pelayanan yang diberikan didasarkan atas keberhasilan dokter memulihkan kembali kesehatan pasien serta rasa nyaman yang dirasakan pasien selama menjalani proses penyembuhan di bangsal keperawatan.

\section{Daftar Pustaka}

Agus M. Hardjana. 2003. Komunikasi intrapersonal $\&$

KomunikasiInterpersonal. Yogyakarta: Penerbit Kanisius.

Agus M. Hardjana. 2007. Komunikasi intrapersonal $\&$

KomunikasiInterpersonal. Yogyakarta: Penerbit Kanisius.

Blaxter, L.,Hughes, C.,\& Tight, M. 2001. How To Research. Maidenhead: Open University Press.

Bittner $1985 . \quad$ Human Communication, Bandung : Remeja Rodas Kary

Deddy Mulyana. 2000. Ilmu Komunikasi: Suatu Pengantar. Bandung: PT. Remaja Rosdakarya

Deddy Mulyana. 2004. Ilmu Komunikasi; Suatu Pengantar.Bandung: PT Remaja Rosdakarya

Fajar Marhaeni. 2009. Ilmu Komunikasi: Teori dan Praktik. Yogyakarta: Graha Ilmu

Indrawati. 2003. Komunikasi Untuk Perawat. Jakarta : EGC.

Kozier,et.al.2004. Fundamentals of nursing ; concepts, process and practice Seventh edition. United States: Pearson Prentice Hall

Suranto. 2003. DinamikaKomunikasi. Erlangga, Jakarta. 
Uber Silalahi. 2006. Metode

Penelitian Sosial, Bandung

: Unpar Press.

Yoeti, Hoka., 1999. Hotel

Customer Service. PT.

Pertja, Bandung. 
